Open Access

\title{
Enhancing green loyalty towards apparel retail stores: A cross-generational analysis on an emerging market
}

\author{
Dan-Cristian Dabija
}

\author{
Correspondence: \\ cristian.dabija@econ.ubbcluj.ro \\ Faculty of Economics and Business \\ Administration, Department of \\ Marketing, Babeș-Bolyai University, \\ Room 125, Teodor Mihali 58-60, RO \\ - 400591, Cluj-Napoca, Romania
}

\begin{abstract}
Faced with an array of scandals and challenges caused by environmental pollution and exploitation of workers, apparel retailers are often compelled to re-think their strategies in compliance with environmental governance, and to implement specific measures aimed at environmental protection and preserving resources. By adopting green-based strategies to reach their target segments, retailers seek not only to capture the attention of different consumer generations, but also to inspire loyalty and encourage them to re-visit stores.

Based on the generational theory and by means of quantitative research addressing four consumer generations in an emerging market, the authors highlight the extent to which clothing retailers are able, by adopting green strategies and consistently implementing environmental protection actions, to attract mainly young consumers to their stores, encouraging the sharing of peer recommendations, increasing purchasing behaviour and invoking loyalty. The article highlights the contribution of green marketing strategies in developing consumer loyalty in an emerging market by offering retailers the possibility of deepening their understanding when approaching different consumer generations.
\end{abstract}

Keywords: Consumer generations, Cross-generational analysis, Apparel retail, Emerging market, Green-oriented retail stores, Consumer loyalty

\section{Introduction}

Industrialization and urbanization, together with world population growth and improvement in standards of living have brought about the diversification and increase of goods and services consumption. This phenomenon has speeded up the depletion of natural resources, greatly reducing nature's capacity for regeneration, and exerting a strong negative impact on the environment (Hubacek et al. 2007). The deterioration of the environment is also enhanced by global warming, environmental pollution, deforestation and decline in flora and fauna (Bandura 2007; Chen and Chai 2010). The planet's renewable resources having been used up at the beginning of August 2016, mankind is living "on credit" (GFN 2016), with even higher consumption of resources envisaged for the future, leading to an accelerated depletion of natural resources. Currently, 1.6 planets would be needed to properly satisfy mankind's consumption needs (WWF 2016), the projection for year 2050 being no less than 2.3 planets

(c) The Author(s). 2018 Open Access This article is distributed under the terms of the Creative Commons Attribution 4.0 International License (http://creativecommons.org/licenses/by/4.0/), which permits unrestricted use, distribution, and reproduction in any medium, provided you give appropriate credit to the original author(s) and the source, provide a link to the Creative Commons license, and indicate if changes were made. 
(WBCSD 2010). In order to overcome this shortage of resources to a certain degree, governments, companies and consumers have combined their efforts into a "green movement" whose purpose is to alleviate or reduce the impact of climate changes and prevent potential ecological disaster (Li et al. 2009).

Environmental issues, climate change, global warming, etc., are hotly debated and widely publicized topics in contemporary society, $69 \%$ of participants in a global research study stating a keen interest (Nielsen 2011). Three out of four interviewees were concerned about air (77\%) and water (75\%) pollution, the use of pesticides $(73 \%)$ and water shortage (73\%). In 2011, their concern for these issues increased by up to $13 \%$ in comparison with 2009 (Nielsen 2011). In 2013, 55\% of respondents (as compared to 50\% in 2011) were willing to pay more for products and services of companies carrying out social and environmental protection projects, while $52 \%$ had purchased at least one product or service from a socially responsible company in the past six months (Nielsen 2014).

In this context, consistent integration of good practices related to environmental protection and the preservation of resources with market-targeting and development strategies for the implementation of environmental protection measures, activities and actions within daily operations has become a pressing matter for modern companies (Lai et al. 2010). More and more companies, regardless of their business sector, have become "green-oriented" in the new millennium (Feng 2010; Dabija and Pop 2013; Papdopolos et al. 2014; Song-Turner and Polonsky 2016). Vertically integrated fashion retailers like H\&M and Inditex pay considerable attention to the use of "green" textiles and recyclable materials, offering consumers recycling schemes, such as the buyback scheme (H\&M Sustainability 2016). Likewise, by adopting a similar orientation towards environmental protection and the integration of these principles into their general business strategy, the U.S. retailers Wal-Mart and Target promote the purchase of organic products, endeavour to reduce energy consumption and use solar energy (Euromonitor 2015a).

An awareness of modern society's growing concern for the need to adopt environmentally responsible behaviour and the challenges associated with this, has led the authors to investigate the preferences expressed by different consumer generations in an emerging market (Romania) over clothing retail chains which implement environmental protection actions. Romania has been chosen as a target market, as it has one of the strongest and most intensive growth of the region and of the European Union, not only in terms of GDP (Obucina 2017), but also regarding consumption behaviour and development of new retail outlets and stores (Dabija and Abrudan 2015).

The paper is based on the generational theory derived from Pilcher (1994) "sociology of generations". According to this theory each generation can be approached by any company as a distinct target market, as the members of each generation share common believes and values, have witnessed similar societal developments and changes and have developed a similar consumption behaviour (Eyerman and Turner 1998; Codrington 2008; Williams and Page 2011). By means of an empirical quantitative study, conducted among Generation $\mathrm{Z}$ and Millennials, Xers and Baby Boomers, the authors highlight the extent to which members of these generations develop loyalty towards greenoriented clothing retailers according to their environmental protection strategies and governance. Following the literature review, the paper presents the research findings and draws pertinent conclusions which could assist clothing retail chains to better understand the differences and disparities among various consumer generations in 
emerging markets, and the opportunity to invoke loyal behaviour as a result of the green actions and environmental protection strategies carried out.

\section{Literature review}

\section{Environmentally conscious companies}

Concern for the problems and challenges arising from excessive environmental pollution, and the need to ensure social equity have given rise to the concept of "sustainable development". The purpose of sustainable development is to strike a balance between economic development, environmental preservation and social responsibility (Sikdar 2003; Martin and Schouten 2012; Dabija and Băbuț 2013) and the implementation of strategies and tactics that both satisfy consumer needs and accomplish company objectives, whilst diminishing the impact on society and the environment (Collins and Kearins 2010; Joshi and Rahman 2015).

Companies that create products and offer services to modern society are increasingly concerned with defining and developing marketing strategies consistent with the principles of sustainable development, focusing on "green" raw materials, processes and components. In this way, they strive to align their corporate objectives with the principles of environmental protection (Karna et al. 2003; Kwok et al. 2016; Chankrajang and Muttarak 2017). Their environmentally responsible behaviour may result from the influence of multiple factors, from national policies to international regulations, standards and procedures of various bodies (International Chamber of Commerce, World Business Council for Sustainable Development, Global Climate Coalition, Business Recycling Coalition etc.), NGOs, charities, etc. (Greenpeace, Friends of Nature, The Climate Project, Environmental Defence Fund, World Wildlife Fund, etc.) (Euromonitor 2015a). These organizations regularly conduct campaigns to raise public awareness about measures and/or ways to preserve the environment, carry out research on the impact of over-consumption and ways to reduce it, develop regulations and codes concerning environmental protection, and both educate and inform consumers. Consumers are the most important group of stakeholders, encouraging companies to adopt measures on behalf of society aimed at preserving resources and/or protecting the environment (Lacy et al. 2010).

Mass media reports that corporate objectives may stand in opposition to environmental protection, as companies are mostly profit-seeking entities which pollute the environment (Prothero and Fitchett 2000). However, a correct strategy involves the consistent implementation of "green" objectives and their integration into all company activities in order to satisfy customer expectations and preferences (Dabija and Pop 2013). Such environmental protection actions can boost company performance by reducing the costs associated with procurement of raw materials and operations, and enabling better allocation of resources in the manufacturing and distribution processes (Taken Smith and Brower 2012). Adherence to a green orientation contributes to the improvement of organizational image and reputation, drawing consumers to the retail store, shaping their preferences and building stronger customer loyalty. Consumers are likely to prefer companies which market green products and brands, and thus contribute to preservation of the environment and ensure the sustainable consumption of resources (environmentally conscious consumers) (Fraj et al. 2011). Environmentally aware companies often receive support from their consumers in the form of reviews and endorsements on the Internet (blogs, forums and social networks) which recommend such "green" companies to other people, 
and contribute to the enhancement of company image by word-of-mouth communication. Recent research suggests that customers tend to be more loyal to companies that exhibit environmentally aware corporate behaviour (Sisodia et al. 2007; Kwok et al. 2016; Chankrajang and Muttarak 2017).

\section{"Green" issues of apparel retailers}

Apparel retail faces problems and challenges, mainly stemming from the failure to consistently implement a "green" strategy: use of toxic chemicals in clothing manufacturing, limited recycling of water used in the production processes, unfair treatment meted out to employees, failure to ensure proper working conditions, limited waste recycling, insufficient use of green or low ecological footprint fabrics and raw materials (Griese and Seyfert 2015), failure to identify concrete ways of re-using old articles, etc. (Dabija et al. 2014). Anyone embracing an environmentally friendly orientation and/or lifestyle, or exhibiting a certain degree of environmental awareness is likely to purchase fewer clothing articles and to wear them more frequently, so as to share in preserving the environment and reducing the consumption of resources, materials or end products (Niinimäki 2011; Niinimäki and Hassi 2011). Such behaviour is looked upon with some disfavour by retailers, because it generates a drop in sales and may lead to financial and job losses, posing a threat to the company's market share (Schramm-Klein and Steinmann 2014). To prevent a drop in sales, apparel, sportswear and footwear retailers often launch collections made from green or low ecological footprint materials (Griese and Seyfert 2015). The effect of such "green fashion" strategies improves consumers' trust in the company's products, enhancing its image and reputation (Niinimäki and Hassi 2011; Kawalek 2015).

The clothing retailer's capacity to properly implement sustainable environmental protection strategies and launch "green" collections is severely tried by the "fast-fashion" phenomenon. This phenomenon has enjoyed rapid growth, revolutionizing and changing substantially customer preferences by offering cheaper clothes modelled on premium and even luxury collections. The products of vertically integrated fast-fashion retailers are now available to more and more segments of consumers (Joy et al. 2012). Prior to the launch of fast-fashion products, collections marketed in specialty stores were replaced two or three times a year. The new trend, however, brought about the partial replacement of collections every four to eight weeks, encouraging consumers to continuously update their wardrobes. This type of consumption encourages the disposal of old-fashioned clothes at the expense of sustainable actions such as their re-use, recycling or donation (Caro and Martínez-de-Albéniz 2014). In the United States, 85\% of annual clothing production ends up in landfills, while in Great Britain, about 350,000 tons of clothing, worth over 140 million GBP, is thrown away annually (Euromonitor 2015a).

Some fast-fashion retailers have started to pay increased attention to environmental protection issues due to recent scandals over the disposal of clothing, which erodes their credibility. Wishing to diminish the quantity of textile waste, apparel and sportswear retailers have launched campaigns to raise consumer awareness about buyback programmes for recycling old-fashioned clothes (for example, the campaigns of H\&M: "Don't Let Fashion Go to Waste"; North Face: "Clothes the Loop"; Puma: "Bring me Back"; Patagonia: "Worn Wear: Better Than New" etc.) (H\&M Sustainability 2016; North Face 2016; Puma 2016; Patagonia 2016). A similar initiative promotes the use of 
recycled materials for producing new garments. Companies such as $H \& M$ and Levi's even introduced "denim recycled" special collections (Levis 2016; H\&M Sustainability 2016). The recycled clothes are used for various purposes, such as the filling of toys, car insulation, etc. (Rabla H\&M 2015; Conscious 2015). Retailers such as H\&M, C\&A and Inditex are increasing the use of sustainable fabric obtained from bamboo, organic cotton, hemp, organic wool, etc. C\&A estimates that it sold around 130 million bio cotton products in 2014 alone, $40 \%$ of its cotton collection being certified to organic standards (C\&A Bio Cotton 2016).

The use of toxic chemicals in clothing manufacturing has also become a major problem, as the textile industry uses over 8000 chemical products annually to produce 400 billion square meters of fabric. Many of these products (colouring agents rich in heavy metals, fixing agents, whiteners, solvents, detergents, etc.) are highly toxic and linger in the environment for long periods, prompting many vertically integrated fashion retailers (Adidas, Gap, Esprit, H\&M, Nike, Puma, C\&A, Primark etc.) and others to make firm commitments to partially or totally eliminate them by the end of 2020 (Textile Pollution 2016; Dabija et al. 2014).

\section{Green issues among consumer generations}

Modern green consumers have a tendency to avoid products that endanger health, have a significant negative impact on the environment, or contravene the principles of sustainability (DiPietro et al. 2013). Consequently, they strive to remove or lessen the causes that may have a negative impact on their future, or irretrievably affect future generations. They also share in educating and making other consumers aware of the dangers posed by consuming such products (Peattie 2001; Kwok et al. 2016; Chankrajang and Muttarak 2017). According to Euromonitor (2015a), 64\% of interviewees, regardless of age, gender, domicile, race, etc., make sustained efforts to minimize as far as possible the impact of their daily actions on the environment. These results show that people are aware about the possible negative effects of the failure to ensure proper environmental protection. In comparison with Millennials and Generation Z members, Baby Boomers and Gen Xers are more concerned about global warming and try to share in halting the phenomenon to the best of their (physical) ability, according to their financial resources or education (DiPietro et al. 2013; Euromonitor 2015a).

Generation X members born between 1965 and 1980 (Taylor and Gao 2014) have much greater awareness of environmental issues than their predecessors, the Baby Boomers. However, recent studies show that they are less oriented towards issues related to environmental protection and preservation than Millennials, because they are also highly influenced by TV advertising (Cheben 2014). Gen Xers' attitude to environmental issues is often superficial, and rather a form of lip service, which varies according to certain contexts and situations. Middle class Gen Xers are eager to purchase healthy or organic food, and use recycled products or products containing recycled materials. Additionally, they show concern for the health of their children (Euromonitor 2009; Young 2015; Euromonitor 2015a).

Millennials or Generation Y, born between 1980 and 1995 (or 2000) (Gurău 2012) are much more concerned with taking responsibility for the environment than Gen Xers and Baby Boomers (Royne et al. 2011). They strongly support regulations, procedures and standards related to the environment and its protection, and are willing to 
support environmentally friendly policies of authorities, organizations and companies, whether they pertain to the development of green energy, or the offering of fiscal incentives for the purchase of hybrid cars (Euromonitor 2015b). Most Millennials, as well as Generation $\mathrm{Z}$ members, are aware that their buying decisions have direct bearing on the green movement around the world (Taken Smith and Brower 2012). These consumers are more willing to buy "green" food and products (Barber et al. 2010), and pay a higher price for food produced in compliance with the principles of sustainability (Laroche et al. 2001; Euromonitor 2015b). They prefer the brands of companies that define their actions in harmony with sustainable development, are actively involved in the welfare of local communities, encourage corporate social responsibility, contribute to the protection of the environment, take care of employees and respect their rights (Martin and Tulgan 2001; Laroche et al. 2001; Taken Smith and Brower 2012). The focus of companies and retailers on Millennials and Generation $\mathrm{Z}$ members especially is all the more relevant, insofar as their number worldwide is very great, being an extremely important target segment (Rajamma et al. 2010).

\section{Consumer loyalty towards retail stores}

Consumer preference for a particular retail format, retail chain or a certain retail store represents a topic which has been intensively studied over time (del Rio et al. 2001; Sirdeshmkh et al. 2002; Yun and Good 2007; Martos-Partal and Gonzales-Benito 2009; Koo and Kim 2013; Swoboda et al. 2014). Customer preference and loyalty to a particular retail store, chain or brand (Khare 2012) is built up with the aid of the tools available to company management, consisting of assortment, price, communication, service, ambiance, or location (Lassar et al. 1995; Swoboda et al. 2014). Also of significance are the retailer's reputation among the target groups (Walsh et al. 2009; Luo and Chung 2015; Pacheco and Rahman 2015; Ziaullah et al. 2016), consumer culture and traditions (Rajamma et al. 2010; Khare 2012) and the image created over time on the basis of trust, awareness, uniqueness and appeal (Lassar et al. 1995; Aaker 1996; del Rio et al. 2001; Verhoef et al. 2007; Dabija and Băbuț 2012; Dabija and Băbuț 2014).

Lifestyle or personality traits may also contribute to the development of loyal behaviour. Therefore, customers' green orientation may represent a driving force for preferring organic products, especially food (Lim et al. 2014). Customer loyalty to a retail brand is expressed mostly through the frequency of purchases (Homburg and Faßnacht 2001), re-purchases (Aaker 1996; Binninger 2008), revisiting and recommendations via word-of-mouth to friends, relatives and acquaintances (del Rio et al. 2001; Sirdeshmkh et al. 2002; Yun and Good 2007; Binninger 2008; Grappi et al. 2013), or preference for the retail brand over other competitors (Oliver 1999).

The desire to recommend a store represents an important premise in building loyalty to that store and the entire retail format, and for returning to the store in the future. Based on other people's recommendations, consumers are better informed in making the decision to purchase a product or prefer a brand in full knowledge of the facts. At the same time, they may discover intrinsic aspects that highlight the brand's added value (Alexandrov et al. 2013). Recent studies have shown the impact of online recommendations and comments posted on various social networks and platforms, young people in particular (Lam et al. 2013; Dabija et al. 2017) being greatly interested in the opinions of others. Influenced by 
such comments, they decide to buy a particular brand, and in time may develop loyal behaviour to the preferred/favourite stores.

\section{Research design and methodology}

An empirical exploratory research, based on a survey was conducted to highlight the extent to which consumers in an emerging market display loyalty towards apparel (including sportswear and footwear) retailers adopting a green strategy based on environmental protection actions. The proposed model under investigation is presented in Fig. 1.

The statements forming the three dimensions under investigation (environmental protection strategy, environmental responsibility, loyalty towards green-oriented retail stores) were operationalized in accordance with the literature (Table 1). All statements were adapted according to the objective of the research. It was implemented using over 50 volunteers (the authors' students) who conducted face-to-face interviews with representatives of four consumer generations (Baby Boomers, Xers, Millennials and Generation $\mathrm{Z}$ members). In order to ensure the randomness of respondent selection, each operator had to contact 30 respondents, every 10 of whom were to be addressed in public places, at their home/work place or near stores. Every respondent had first to state if he/she had shopped recently (past three months) in fashion/footwear/sportswear retail stores. If they had not shopped in any of these, they were dropped. If they had shopped accordingly, then they had to name up to six such stores which they had visited most frequently. For the first questionnaire, the operator had to take the store named as the first place, for the second questionnaire, the store named in second place, etc. If a questionnaire had more than $5 \%$ of unfilled items/answers, it was dropped before conducting the analysis.

Approximately 1200 questionnaires were administered in 2016, of which only 1068 were validated. In order to ensure socio-demographic sample representativeness, the operators were previously instructed to apply quota sampling according to age and gender (Churchill 1991) in selecting the respondents and conducting the interviews, in compliance with the distribution of Romania's population, as shown in the statistical yearbook of 2014 (Romanian Statistical Annuary, 2014). The operators had to contact respondents living in rural areas, and in small (under 20,000 inhabitants), middle (20,000-100,000 inhabitants) and big cities (over 100,000 inhabitants). Respondents were asked to express their agreement with the statements presented in Table 1 on a five-point Likert scale. Following data collection and systematization, several statistical tests were conducted to check the data accuracy, reliability and internal consistency. This was done with the help of Cronbach $\alpha$ (>0.7), "item-to-total" correlation, Kaiser-Meyer-Ohlkin (>0.7) criterion, Bartlett's sphericity (see Table 2) and the fit indices for the model in Fig. 1. The model has been validated statistically by using structural equation modelling with AMOS (Churchill 1991).

As the internal consistency of data with respect to the considered dimensions (environmental protection strategy, retailers' responsibility towards the environment, loyalty

\begin{tabular}{||c|c|}
\hline Environmental Protection Strategy & $\begin{array}{c}\text { Loyalty towards Green Oriented } \\
\text { Retail Stores }\end{array}$ \\
\hline \hline Environmental Responsibility
\end{tabular}

Fig. 1 The proposed model 
Table 1 Factor analysis of the investigated dimensions

\begin{tabular}{|c|c|c|c|}
\hline Construct [Literature] & Apparel retailers... & $\begin{array}{l}\text { Loadings } \\
\text { (EFA) }\end{array}$ & FIT \\
\hline \multirow[t]{4}{*}{$\begin{array}{l}\text { Environ-mental Responsi-bility Bearden et } \\
\text { al. 2006; Walsh and Beatty } 2007\end{array}$} & $\begin{array}{l}\text {... seem to be responsible towards the } \\
\text { environment. }\end{array}$ & 0.874 & \multirow{4}{*}{$\begin{array}{l}\text { EV: } 2.795 ; \\
\% \text { of var: } \\
34.93\end{array}$} \\
\hline & $\ldots$ are careful to protect the environment. & 0.769 & \\
\hline & $\begin{array}{l}\ldots \text { are willing to renounce part of their } \\
\text { profit to ensure a clean environment. }\end{array}$ & 0.725 & \\
\hline & $\begin{array}{l}\text {... seem to support good environment } \\
\text { protection causes. }\end{array}$ & 0.673 & \\
\hline \multirow[t]{4}{*}{$\begin{array}{l}\text { Environ-mental Protection Strategy } \\
\text { Bearden et al. 2006, Dabija and Grant 2016, } \\
\text { Lastovicka et al. } 1999\end{array}$} & $\begin{array}{l}\text {... think about the future of children and } \\
\text { grandchildren so that they may live in an } \\
\text { unpolluted environment. }\end{array}$ & 0.796 & \multirow[t]{4}{*}{$\begin{array}{l}\text { EV: } 2.371 ; \\
\% \text { of var: } \\
29.63\end{array}$} \\
\hline & ... show concern for the future of society. & 0.754 & \\
\hline & $\begin{array}{l}\text {... follow the example of western countries } \\
\text { in this regard (pollution reduction etc.). }\end{array}$ & 0.664 & \\
\hline & ... changes in legislation. & 0.645 & \\
\hline \multirow{5}{*}{$\begin{array}{l}\text { Loyalty towards green- oriented retail } \\
\text { stores Dabija and Grant 2016, Lastovicka et } \\
\text { al. 1999, Nasir and Karakaya } 2014\end{array}$} & $\begin{array}{l}\text { I intend to buy clothes made of organic } \\
\text { materials in the next three months. }\end{array}$ & 0.913 & \multirow{5}{*}{$\begin{array}{l}\text { EV: } 1.98 \\
\% \text { of var: } \\
19.35\end{array}$} \\
\hline & $\begin{array}{l}\text { I will recommend retailers who sell "green" } \\
\text { clothes (clothes made of organic materials) } \\
\text { to my friends and acquaintances. }\end{array}$ & 0.867 & \\
\hline & $\begin{array}{l}\text { I will buy more "green" clothes in the } \\
\text { future. }\end{array}$ & 0.854 & \\
\hline & $\begin{array}{l}\text { In the near future I will try other "green" } \\
\text { clothes which I have not bought before. }\end{array}$ & 0.821 & \\
\hline & $\begin{array}{l}\text { If I happen to seek "green" clothes/clothes } \\
\text { made of organic materials and they are not } \\
\text { available in the nearby stores, then I will } \\
\text { seek them in other stores, even if they are } \\
\text { a long distance away. }\end{array}$ & 0.801 & \\
\hline
\end{tabular}

Obs.: Extraction Method: Principal Axis Factoring. Rotation Method: Oblimin with Kaiser Normalization Sources: Bearden et al. 2006 Dabija and Grant 2016; Lastovicka et al. 1999; Nasir and Karakaya 2014; Walsh and Beatty 2007

towards green- oriented retail stores) has been noted as good, the data were included in a single exploratory factor analysis (Walsh and Beatty 2007). The results show that environmental protection strategy and retailers' responsibility towards the environment (Table 1) which determine loyalty towards green-oriented retail stores may be properly delineated. The fit indices exceed the minimum thresholds for this type of investigation (Churchill 1991; Forza and Filippini 1998; Ju et al. 2006): $\mathrm{KMO}=0.846, \mathrm{X}^{2}=3156.155^{* * * * * * *} ; \mathrm{df}=381$ ).

The first factor in the factor analysis with an eigenvalue of 2.795 and an explained variance of $34.932 \%$ is retailers' responsibility towards the environment. It is followed

Table 2 Results of testing data validity and reliability

\begin{tabular}{|c|c|c|c|c|c|c|}
\hline Dimension & $\begin{array}{l}\text { No. of } \\
\text { items }\end{array}$ & $\begin{array}{l}a^{a} \\
>0.7\end{array}$ & $\begin{array}{l}\mathrm{KMO}^{\mathrm{b}} \\
>0.7\end{array}$ & $x^{2} ; d f ; p^{c}$ & Eigen-value & $\%$ variance \\
\hline Environmental protection strategy & 4 & 0.804 & 0.838 & $1459.43 ; 26 ; *$ & 2.531 & 63.282 \\
\hline Environmental responsibility & 4 & 0.823 & 0.760 & $1651.49 ; 37 ;{ }^{*}$ & 2.622 & 65.541 \\
\hline $\begin{array}{l}\text { Loyalty towards green-oriented retail } \\
\text { store }\end{array}$ & 5 & 0.900 & 0.864 & $3319.839 ; 43 ; *$ & 3.588 & 71.759 \\
\hline
\end{tabular}

${ }^{\mathrm{a}}$ Cronbach a coefficient (check of data reliability)

${ }^{b}$ Kaiser-Meyer-Ohlkin criterion (exploratory factor analysis in SPSS) for each dimension

'Bartlett's sphericity test $\left(x^{2}-\right.$ hi square, $d f$ - degrees of freedom, $p$ (probability); ${ }^{*} p<0.001$ )

Source: own research 
by environmental protection strategy (eigenvalue of 2.371, explained variance of 29.632\%). Both factors have a direct effect on the investigated phenomenon and contribute to its expansion. The model presented in Fig. 1 was validated using structural equation modelling (AMOS) for all four generations considered as well as for each individual generation. In each case, the fit indices exceed the minimum thresholds $(>0,8$; $\leq 0,08$ ) specified in the literature (Forza and Filippini 1998; Ju et al. 2006). They are shown in Table 3, and the results can be interpreted.

\section{Sample structure}

The 1068 valid questionnaires contain Romanian respondents' assessment of various stores, marketing all sorts of apparel, including stores selling sportswear and footwear articles (Table 4). Therefore, the authors sought to have total representativeness of the answers concerning clothing retail (Dhurup et al. 2013), as the assessment covered almost all clothing retail chains operating in the cities of Romania. In addition to the assessment of specialized stores presented in Table 5, the research included the assessment of fashion assortments marketed by international hypermarket chains: Auchan, Cora and Carrefour.

Respondents were required to state certain socio-demographic characteristics: age, gender, education and income. Depending on their year of birth, they were classified in one of the four analysed generations: 246 persons (23\% of the sample) belonged to Generation Z, born between 1995 and 2000, 401 persons (37.5\%) were Millennials (born between 1980 and 1994), 278 (26\%) were Gen Xers (born between 1965 and 1979) and 143 (13.5\%) were Baby Boomers (born between 1945 and 1964). This breakdown by generation was made according to indications in the international literature (Cheung et al. 2008; Weingarten 2009; Taken Smith 2011; Gurău 2012; Loroz and Helgeson 2013; Eastman et al. 2014; Young 2015). 46.3\% of respondents were men and 53.7\% were women, corresponding to the records in the latest Statistical Yearbook (2014). The variation did not exceed the initially established quotas by more than $1 \%$. However, a possible bias was that fact that only persons over 15 were included in Generation Z. The purpose was to obtain answers from young people close to the age of majority and starting to earn their own income and make personal buying decisions (Swoboda et al. 2014).

Four hundred seventy-eight persons (44.8\%) had a university education (bachelor, master's, PhD degree), 380 (35.6\%) had received secondary education and 148 (13.8\%) had had vocational training education (Table 4). Recent studies show that education and income are determining factors in increasing the likelihood that a person will purchase green products, contributing to environmental protection (Roberts 1996), in

Table 3 Determinants of green loyalty among consumer generations

\begin{tabular}{|c|c|c|c|c|c|}
\hline Effects & $\begin{array}{l}\text { All } \\
\text { generations }\end{array}$ & $\begin{array}{l}\text { Baby } \\
\text { Boomers }\end{array}$ & $x$ & Millennials $(Y)$ & Z \\
\hline No of cases & 1068 & 143 & 278 & 401 & 246 \\
\hline $\begin{array}{l}\text { Environmental protection strategy } \rightarrow \\
\text { Loyalty }\end{array}$ & $0.524^{* * * *}$ & $0.537^{* * * *}$ & $0.527^{* * * *}$ & $0.669^{* * * *}$ & $0.690^{* * * *}$ \\
\hline Environmental Responsibility $\rightarrow$ Loyalty & $0.161^{* *}$ & $0.095^{\text {n.s. }}$ & $0.161^{\text {n.s. }}$ & $0.148^{*}$ & $0.157^{* *}$ \\
\hline \multicolumn{6}{|c|}{ 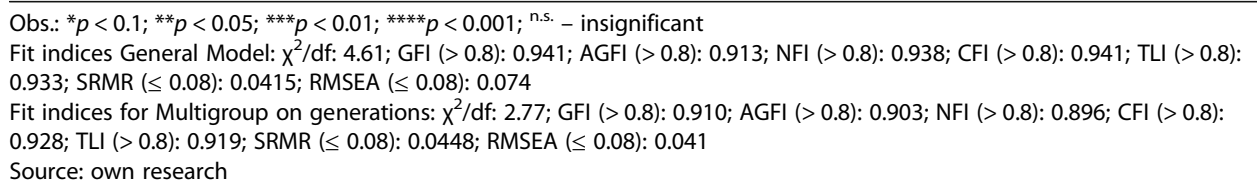 } \\
\hline
\end{tabular}


Table 4 Socio-demographic characteristics of the sample

\begin{tabular}{|c|c|c|c|c|c|c|c|c|c|c|}
\hline \multirow[t]{2}{*}{ Generations } & \multicolumn{2}{|c|}{ Baby Boomers } & \multicolumn{2}{|l|}{$x$} & \multicolumn{2}{|c|}{ Millennials } & \multicolumn{2}{|l|}{ Z } & \multicolumn{2}{|l|}{ Total } \\
\hline & $\mathrm{n}$ & $\%$ & $\mathrm{n}$ & $\%$ & $\mathrm{n}$ & $\%$ & $\mathrm{n}$ & $\%$ & $\mathrm{n}$ & $\%$ \\
\hline \multicolumn{11}{|l|}{ Gender } \\
\hline Male & 66 & 6.2 & 109 & 10.2 & 204 & 19.1 & 115 & 10.8 & 494 & 46.3 \\
\hline Female & 77 & 7.2 & 169 & 15.8 & 197 & 18.4 & 131 & 12.3 & 574 & 53.7 \\
\hline Total & 143 & 13.4 & 278 & 26.0 & 401 & 37.5 & 246 & 23.0 & 1068 & 100.0 \\
\hline \multicolumn{11}{|l|}{ Highest level of education completed } \\
\hline High school & 32 & 3.0 & 59 & 5.5 & 97 & 9.1 & 192 & 18.0 & 380 & 35.6 \\
\hline Vocational training & 29 & 2.7 & 44 & 4.1 & 62 & 7.5 & 13 & 1.2 & 148 & 13.8 \\
\hline Higher education & 69 & 6.5 & 167 & 15.6 & 227 & 27.6 & 15 & 1.4 & 478 & 44.8 \\
\hline Other forms of education & 13 & 1.2 & 8 & 0.7 & 15 & 1.8 & 26 & 2.4 & 62 & 5.8 \\
\hline Total & 143 & 13.4 & 278 & 26.0 & 401 & 37.5 & 246 & 23.0 & 1068 & 100.0 \\
\hline \multicolumn{11}{|l|}{ Monthly net income (lei) } \\
\hline Below minimum wages* & 6 & 0.6 & 5 & 0.5 & 21 & 2.0 & 47 & 4.4 & 79 & 7.4 \\
\hline minimum* - average ${ }^{* *}$ wages & 79 & 7.4 & 94 & 8.8 & 186 & 17.4 & 67 & 6.3 & 426 & 39.9 \\
\hline Between 1 and 2 average wages ${ }^{* *}$ & 36 & 3.4 & 125 & 11.7 & 126 & 11.8 & 12 & 1.2 & 300 & 28.1 \\
\hline Over 2 average wages** & 11 & 1.0 & 32 & 3.0 & 21 & 2.0 & 2 & 0.2 & 66 & 6.2 \\
\hline Undisclosed wages & 11 & 1.0 & 22 & 2.1 & 47 & 4.4 & 117 & 11.0 & 197 & 18.4 \\
\hline Total & 143 & 13.4 & 278 & 26.0 & 401 & 37.5 & 246 & 23,0 & 1068 & 100.0 \\
\hline
\end{tabular}

enhancing consumers' environmentally friendly orientation, and in selecting companies involved in "green initiatives" (DiPietro et al. 2013) and implementing proper environmental governance (Kwok et al. 2016; Chankrajang and Muttarak 2017).

One hundred ninety-seven respondents (18.4\%) did not state their income, possibly because they did not have a stable income or lived off their parents, which was mostly true in the case of Generation $\mathrm{Z}$ members. $7.4 \%$ had an income below the national minimum wage, most of them belonging to Generation Z. At the time of the research, almost $40 \%$ of respondents, belonging to all four analysed generations, earned between the national minimum wage (205 EUR) and the average net wage (460 EUR). $28.1 \%$ of respondents earned between one and two average net wages (460-920 EUR), most of them being Millennials (11.8\%) and Gen Xers (11.7\%). The number of Gen Xers who earned over two average net wages (920 EUR) was greater (3\%) than that of Millennials (2\%) and Baby Boomers (1\%). If

Table 5 Domestic vs international retail chains

\begin{tabular}{llll}
\hline $\begin{array}{l}\text { Chain } \\
\text { Articles }\end{array}$ & Apparel & Sportswear & Footwear \\
\hline Romanian & Bigotti, Guara, Effect, Eponje, IQ & \\
& & DH Sport, Fashionsport & $\begin{array}{l}\text { Benvenutti, Ameli, } \\
\text { Marelbo, Clujana }\end{array}$ \\
International & $\begin{array}{l}\text { Zara, Bershka, Stradivarius, New Yorker, C\&A, H\&M, } \\
\text { Calvin Klein, Hugo Boss, Lee Cooper }\end{array}$ & $\begin{array}{l}\text { Decathlon, Intersport, } \\
\text { Hervis, Adidas, Nike }\end{array}$ & $\begin{array}{l}\text { Humanic, Ecco, } \\
\text { Deichmann }\end{array}$ \\
\hline
\end{tabular}


one looks at the net average income of Millennials, most of them had an income lower than that of Gen Xers and Baby Boomers, respectively (Table 4).

\section{Results and discussion}

The analysis of the model in Fig. 1 using structural equations (AMOS) reveals that the preference for clothing stores where customers will re-buy, revisit or recommend depends on the extent to which these retailers conduct environmental protection activities and consistently pursue a "green" strategy $\left(0.524^{* * * * *)}\right)$. Consumers tend to revisit and repurchase from retailers which market clothing made of "green" and/or organic materials. They exhibited a positive inclination to recommend such retailers to friends and acquaintances (Table 3). The more environmental protection and best practice actions implemented, the greater the likelihood of the store or retail chain being revisited by, and gaining the loyalty of people. The adoption by companies of a strategic environmental protection orientation by observing laws, standards and regulations to ensure a less polluted environment for future generations exerts a highly intensive and significant influence on consumer loyalty, regardless of generation. The strength of this relationship derives from the fact that clothing retailers often adopt "green" practices both in domestic markets, where they have factories or production units, and in outlet markets, so as to capture consumers' attention, draw them to the store and gain their loyalty.

The lower intensity and reduced significance of the relationship between a retailer's actual responsibility towards the environment and the consumer's preference for a retail store and willingness to revisit or recommend a green-oriented retail store $\left(0.161^{* * *}\right)$ may be accounted for by the fact that, despite retailers' stated environmental protection objectives within their general strategies, their actions and activities to preserve resources and protect the environment, at least in the emerging market under analysis, were very few, or were unfamiliar to respondents. It is true that the scandals surrounding some clothing retailers over excessive environmental pollution in the Asian countries where they have production units were sparsely covered by the media. It has only been during the last 10 to 15 years that the emerging market analysed was approached more intensely by clothing retailers, which means that respondents had not had sufficiently rich experience of the retail brands. At the same time, it has been noted that consumers in emerging markets develop a "benchmark" (own standard) for good practice against which to perceive and compare the actions of a new retailer over a longer period of time (Dabija et al. 2014).

According to the opinion of the members of all generations, environmental protection strategies implemented by clothing retailers has a decisive role in consumers' preferring, revisiting and recommending green-oriented apparel stores to other people. However, the general perception of the analysed retailers' environmental responsibility reveals a much lower and even insignificant influence on the investigated phenomenon (Table 3). The greatest concern for retailers' green strategy was exhibited by the young generations, $\mathrm{Z}\left(0.690^{* * * * * *}\right)$ and Millennials $\left(0.669^{* * * * *}\right)$. These generations are the most informed, as they spend much time online on various portable devices accessing information and constantly looking for new things (Young 2015; Dabija and Grant 2016; Dabija et al. 2017). They are also more actively involved in cultural activities and social events than the previous generations, and prefer companies with good environmental protection strategies (Harwood 2002; Heaney 2007), which implement socially responsible policies (Furlow 2011). Therefore, the existence of environmental responsibility 
demonstrated by actions and activities directed at protecting the environment plays an important role, but is less significant in developing loyal behaviour in Generation $\mathrm{Z}$ $\left(0.157^{* * *}\right)$ and Millennials $\left(0.148^{* * *}\right)$ towards the green-oriented stores.

For the active and mature Gen Xers, the retailer's implementation of a proper environmental protection strategy provides a good reason to select, recommend and revisit the store. However, such a strategy seems to be less relevant to them than to their successors (Millennials and Generation Z), albeit highly significant $\left(0.527^{* * * * *)}\right)$. The extent to which clothing retailers implement environmental protection actions is not significant $\left(0,161^{\text {n.s. }}\right)$, probably because, as in the case of the other generations, environmental protection is generally a topic of little importance, Gen Xers being more pragmatic and concerned with family, education and friends (Euromonitor 2009). They spend less time online, which means they are quite sceptical about new things, and do not allow themselves to be easily influenced (Glass 2007; Hernaus and Pološki-Vokic 2014).

Baby Boomers are also concerned about whether the analysed retailers have a strategy for protecting the environment $\left(0.537^{* * \cdots * *}\right)$. This is probably due to their desire to leave the legacy of a "greener" environment, as "clean" as possible and less polluted. However, they do not notice, or are not interested in the concrete actions $\left(0.095^{\text {n.s. }}\right)$ of apparel retailers putting into practice strategies and consistently pursuing proper environmental governance within their own activities (Table 3).

\section{Conclusions}

The present research emphasizes significant differences across consumer generations with respect to their perception of clothing retailers' general environmental protection strategies and actions taken for their implementation. In fact, the strengthening of general business strategies for environmental governance, and the implementation of concrete measures to preserve the environment led to a preference for, and loyalty towards green-oriented apparel retail stores. Young consumers (Generation $\mathrm{Z}$ and Millennials) were the target segments which developed the strongest loyalty towards green-oriented apparel retail stores when confronted with environmental protection actions implemented by such retailers. Gen Xers, who had experienced different living conditions to Millennials or Generation Z members were also green-oriented, and developed loyalty towards retail stores that focused on environmental governance, but to a lesser extent. Baby Boomers, represented mostly by people who were retired or about to retire, developed loyalty towards green-oriented apparel stores based on the extent to which they understood and/or were able to assess the environmental protection strategies implemented by such stores. Baby Boomers were less sensitive to the environmentally responsible actions of green-oriented retailers, because for them, green aspects and environmental protection was probably never of great concern.

The results of the study show that younger consumer generations in an emerging market such as Romania are equally sensitive to the environmental protection strategies and actions implemented by apparel retailers as their western counterparts (Royne et al. 2011), and display greater loyalty towards retailers who rely on proper environmental governance. When older consumers like Gen Xers or Baby Boomers were analysed regarding the antecedents of their loyalty towards green-oriented retailers, environmental governance tended to be less important for them. This could be because they are often influenced by advertising (Cheben 2014) to evaluate superficial environmental issues (Young 2015; Euromonitor 2015a). As western literature shows, these consumers tend to be concerned about global 
warming, but do not necessarily make any correlation between this global issue and retailers' environmental governance, or the importance of implementing a green strategy. Baby Boomers adopted loyal behaviour, preferring, revisiting and recommending greenoriented clothing retailers based more on their general environmental protection strategies, and less on specific actions.

The research shows that, especially in an emerging market like Romania, clothing retailers' environmental protection strategy is a highly important factor in shaping the loyal behaviour of consumer generations. Romanians pay great attention and attach a high significance to sustainable apparel retailers who rely on proper environmental governance. Further research could highlight the extent to which cross-generational personal values may also lead to the fostering of a strong retailing brand image, promoting satisfaction and loyalty. A comparative perspective between food and non-food retailing, as well as between different non-food retail formats might also highlight specific aspects and preferences, which could encourage loyal behaviour.

From a theoretical perspective, the paper contributes to the extension of the literature on emerging markets and environmental strategies in retailing, as well as to that on generational theory, highlighting a proper understanding of the measures through which retail brands may act towards consumers and position themselves based on environmental governance. From a managerial perspective, the paper might help retailers in understanding the discrepancies between younger consumer generations in an emerging market whose behaviour is similar to their western counterparts, and older consumer generations, who could be characterized as being less concerned about "modern" issues such as environmental responsibility.

\section{Acknowledgements}

The author would like to thank to Associate Prof. Raluca Babut, PhD, member of the research grant CNCS - UEFISCDI, project number PN-II-RU-TE-2014-4-0312 who contributed with her experience and knowledge and gave some critical views regarding the manuscript and the structure of the article. The author also thanks Liz Hollis from UK for making the proof read of the article. The author also thanks to the volunteers who administered the questionnaire and helped collecting the data.

Funding

"This work was supported by a grant of the Romanian National Authority for Scientific Research and Innovation, CNCS - UEFISCDI, project number PN-II-RU-TE-2014-4-0312". The author of the article is the principal investigator of the project financed by CNCS - UEFISCDI. The author designed this article, collected the data, made the analysis and the interpretation of data and wrote the manuscript.

\section{Availability of data and materials}

The data was collected by face to face interviews during 2016. The collection of data was supported by a research grant of the Romanian National Authority for Scientific Research and Innovation, CNCS - UEFISCDI, project number PN-II-RU-TE-2014-4-0312". The author of this article was was principal investigator (project leader) of the project.

\section{Author's contributions}

The author of the paper has the entire contribution to the paper. The author read and approved the final manuscript and for multiple authors.

\section{Competing interests}

The authors declare that they have no competing interests.

\section{Publisher's Note}

Springer Nature remains neutral with regard to jurisdictional claims in published maps and institutional affiliations.

Received: 18 February 2018 Accepted: 8 March 2018

Published online: 16 March 2018

\section{References}

Aaker, D. (1996). Measuring brand equity across products and markets. California Management Review, 3(3), $102-120$. Alexandrov, A., Lilly, B., \& Babakus, E. (2013). The effects of social- and self-motives on the intentions to share positive and negative word of mouth. Journal of the Academy of Marketing Science, 41(5), 531-546. 
Bandura, A. (2007). Impeding ecological sustainability through selective moral disengagement. International Journal of Innovation and Sustainable Development, 2(1), 8-35.

Barber, N., Taylor, D. C., \& Strick, S. (2010). Selective marketing to environmentally concerned wine consumers: A case for location, gender and age. Journal of Consumer Marketing, 27(1), 64-75.

Bearden, W. O., Bruce, M., \& Nevins, J. L. (2006). A measure of long-term orientation: Development and validation. Journal of the Academy of Marketing Science, 34(3), 456-467.

Binninger, A. S. (2008). Exploring the relationships between retail brand and consumers store loyalty. International Journal of Retail and Distribution Management, 36(2), 94-110.

C\&A Bio Cotton (2016). Bio cotton - Taking organic mainstream. https://www.c-and-a.com/ro/ro/corporate/company/ sustenabilitate/bio-cotton/. Accessed 12 Mar 2018.

Caro, F., \& Martínez-de-Albéniz, V. (2014). How fast fashion works: Can it work for you, too? IESE Insight Review, 21, 58-65

Chankrajang, T., \& Muttarak, R. (2017). Green returns to education: Does schooling contribute to pro-environmental Behaviours? Evidence from Thailand. Ecological Economics, 131, 434-448.

Cheben, J. (2014). Effectiveness of TV advertising when targeting generations $Y$ and X. In V. Kubickova \& D. Brevenikova (Eds.), $5^{\text {th }}$ international scientific conference on trade, international business and tourism: Application of knowledge in process of business Dynamization in Central Europe (pp. 178-186). Mojmirovce: Eknom.

Chen, T. B., \& Chai, L. T. (2010). Attitude towards the environment and green products: Consumers' perspective. Management Science and Engineering, 4(2), 27-39.

Cheung, L., Harker, D., \& Harker, M. (2008). The state of the art of advertising from the consumers' perspective: A generational approach. The Marketing Review, 8(2), 125-146.

Churchill, G. A. (1991). Marketing research: Methodological foundation (5th ed.). Fort Worth: The Dryden Press.

Codrington, G. (2008). Detailed introduction ro generational theory. Tomorrow today (pp. 1-16).

Collins, E., \& Kearins, K. (2010). Delivering on Sustainability's global and local orientation. Academy of Management Learning \& Education, 9, 499-506.

Conscious (2015). H\&M conscious foundation. https://sustainability.hm.com/content/dam/hm/about/documents/ masterlanguage/CSR/2015\%20Sustainability\%20report/HM_SustainabilityReport_2015_final_com_5.pdf. Accessed 19 June 2015.

Dabija, D. C., \& Abrudan, I. N. (2015). Retailing in Romania: From statist to nearly capitalist. European Retail Research, 27(2), 55-92.

Dabija, D. C., \& Băbuț, R. (2012). Building loyalty in retailing through in-store-management and communication. In C. Brătianu, G. Brătucu, D. Lixăndroiu, N. A. Pop, \& S. Văduva (Eds.), Proceedings of the 7th international conference on business excellence. 12-13 October 2012, volume I (pp. 166-172). Braşov: Transylvania University Publishing House.

Dabija, D. C., \& Băbuț, R. (2013). An approach to sustainable development from Tourist's perspective. Empirical evidence in Romania. Amfiteatru Economic, 15(Special Issue 7), 617-633.

Dabija, D. C., \& Băbuț, R. (2014). Enhancing Consumers' satisfaction and loyalty of retailers in Romania through store ambiance and communication. Procedia Economics and Finance, 15, 371-382.

Dabija, D. C., Băbuț, R., Dinu, V., \& Lugojan, M. (2017). Cross-generational analysis of information search based on social Media in Romania. Transformations in Business \& Economics, 16(41), 248-270.

Dabija, D. C., \& Grant, D. (2016). Investigating shopping experience and fulfillment in Omnichannel retailing: A proposed comparative study in Romanian and UK of generation Y consumers. In D. Menachof (Ed.), Doing the right things. Ethical issues in logistics and supply chair. Abstracts of the 21st annual logistics research network conference. Corby: Northamptonshire: The Logistics Institute.

Dabija, D. C., \& Pop, C. M. (2013). Green marketing - Factor of competitiveness in retailing. Environmental Engineering and Management Journal, 12(2), 393-400.

Dabija, D. C., Pop, N. A., \& Szentesi, S. (2014). A customer-oriented perspective on retail brand equity in the fashion industry. Industria Textilă, 65(1), 37-46.

del Rio, B., Vasquez, R., \& Iglesias, V. (2001). The effects of brand associations on consumer response. Journal of Consumer Marketing, 18(5), 410-425.

Dhurup, M., Mafini, C., \& Mathaba, R. L. (2013). Store image factors influencing store choice among sportswear consumers: Baseline findings from South Africa. Mediterranean Journal of Social Science, 4(14), 359-370.

DiPietro, R. B., Gregory, S., \& Jackson, A. (2013). Going green in quick-service restaurants: Customer perceptions and intentions. International Journal of Contemporary Hospitality Tourism Administration, 14, 139-156.

Eastman, J. K., Iyer, R., Liao-Troth, S., Williams, D. F., \& Griffin, M. (2014). The role of involvement on millennials' mobile technology behaviors: The moderating impact of status consumption, innovation, and opinion leadership. Journal of Marketing Theory and Practice, 22(4), 455-470.

Euromonitor (2009), The World's gen Xers: Latchkey kids (29-44s) come into their own. http://www.euromonitor.com/ the-worlds-gen-xers-latchkey-kids-29-44s-come-into-their-own/report. Accessed 7 June 2016.

Euromonitor (2015a). Eco worriers: Global green behaviour and market impact. www.euromonitor.com/eco-worriersglobal-green-behaviour-and-market-impact/report. Accessed 5 May 2016.

Euromonitor (2015b). Millennials impact of their behaviour on global consumer markets. www.euromonitor.com/ millennials-impact-of-their-behaviour-on-global-consumer-markets/report. Accessed 6 June 2016.

Eyerman, R., \& Turner, B. S. (1998). Outline of a theory of generations. European Journal of Social Theory, 1(1), 91-106.

Feng, F. D. (2010). "Green" company or "green" consumers: A Kantian retrospective. International Journal of Social Economics, 37(10), 779-783.

Forza, C., \& Filippini, R. (1998). TQM impact on quality conformance and customer satisfaction: A causal model. International Journal of Production Economics, 55, 1-20.

Fraj, E., Martinez, E., \& Matute, J. (2011). Green marketing strategy and the Firm's performance: The moderating role of environmental culture. Journal of Strategic Marketing, 19, 339-355.

Furlow, N. E. (2011). Find us on Facebook: How cause marketing has embraced social media. Journal of Marketing Development and Competitiveness, 5(6), 61-64.

GFN (2016). Earth overshoot day 2016. https://www.overshootday.org/newsroom/past-earth-overshoot-days/. Accessed 10 Aug 2016. 
Glass, A. (2007). Understanding generational differences for competitive success. Industrial and Commercial Training, $39(2), 98-103$.

Grappi, S., Romani, S., \& Bagozzi, R. P. (2013). The effects of company offshoring strategies on consumer responses. Journal of the Academy of Marketing Science, 41, 683-704.

Griese, K. M., \& Seyfert, W. (2015). Nachhaltigkeits-Controlling bei Puma SE. In W. Pepels (Ed.), Fallstudien zum Marketing (pp. 277-290). Herne: Kiel Verlag.

Gurău, C. (2012). A life-stage analysis of consumer loyalty profile: Comparing generation X and millennial consumers. Journal of Consumer Marketing, 29(2), 103-113.

H\&M Sustainability (2016). H\&M Reduce, reuse, recycle. https://about.hm.com/en/sustainability/get-involved/recycleyour-clothes.html. Accessed 8 Aug 2016.

Harwood, M. (2002). Talking to the generations: How to market to different age groups. Community Banker, 11(7), 28-33.

Heaney, J. G. (2007). Generations X and Y's internet banking usage in Australia. Journal of Financial Services Marketing, $11(3), 196-210$.

Hernaus, T., \& Pološki-Vokic, N. (2014). Work Design for Different Generational Cohorts. Journal of Organizational Change Management, 27(4), 615-641.

Homburg, C., \& Faßnacht, M. (2001). Kundennähe, Kundenzufriedenheit und Kundenbindung bei Dienstleistungsunternehmen. In M. Bruhn \& H. Meffert (Eds.), Handbuch Dienstleistungsmanagement. Von der strategischen Konzeption zur praktischen Umsetzung (pp. 441-463). Wiesbaden: Gabler.

Hubacek, K., Guan, D., \& Barua, A. (2007). Changing lifestyles and consumption patterns in developing countries: A scenario analysis for China and India. Futures, 39(9), 1084-1096.

Joshi, Y., \& Rahman, Z. (2015). Factors affecting green purchase behaviour and future research directions. International Strategic Management Review, 3, 128-143.

Joy, A., Sherry Jr., J. F., Venkatesh, A., Wang, J., \& Chan, R. (2012). Fast fashion, sustainability, and the ethical appeal of luxury brands. Fashion Theory, 16(3), 273-296.

Ju, T. L., Lin, B., Lin, C., \& Kuo, H. J. (2006). TQM critical factors and KM value chain activities. Total Quality Management, 17(3), 373-393.

Karna, J., Hansen, E., \& Juslin, H. (2003). Social responsibility in environmental marketing planning. European Journal of Marketing, 37, 848-871.

Kawalek, E. (2015). Why H\&M Destroys Unsold Clothes. http://www.slate.com/blogs/xx_factor/2010/01/07/why_hm_ destroys_unsold_clothes.html. Accessed 20 Aug 2015.

Khare, A. (2012). Influence of culture on Indian consumers' preference to shop at small retail stores. Journal of Global Marketing, 25(2), 100-111.

Koo, W., \& Kim, Y. K. (2013). Impacts of store environmental cues on store love and loyalty: Single-brand apparel retailers. Journal of International Consumer Marketing, 25(2), 94-106.

Kwok, L., Huang, Y. K., \& Hu, L. (2016). Green attributes of restaurants: What really matters to consumers? International Journal of Hospitality Management, 55, 107-117.

Lacy, P., Cooper, T., Hayward, R. \& Neuberger, L. (2010). A new era of sustainability. UN global compact-Accenture CEO study. https://www.unglobalcompact.org/docs/news_events/8.1/UNGC_Accenture_CEO_Study_2010.pdf. Accessed 26 July 2016.

Lai, K., Cheng, T. C. E., \& Tang, A. K. Y. (2010). Green retailing and its success factors. California Management Review, $52(2), 6-31$.

Lam, S., Ahearne, M., Mullins, R., Hayati, B., \& Schillewaert, N. (2013). Exploring the dynamics of Antecendents to consumer-brand identification with a new brand. Journal of the Academy of Marketing Science, 41(2), 234-252.

Laroche, M., Bergeron, J., \& Barbaro-Forleo, G. (2001). Targeting consumers who are willing to pay more for environmentally friendly products. Journal of Consumer Marketing, 18(6), 503-520.

Lassar, W., Mittal, B., \& Sharma, A. (1995). Measuring customer - Based brand equity. Journal of Consumer Marketing 12(4), 11-19.

Lastovicka, J. L., Bettencourt, L. A., Hughner, R. S., \& Kuntze, R. J. (1999). Lifestyle of the tight and frugal: Theory and measurement. Journal of Consumer Research, 26, 85-98.

Levis (2016). Denim Recycled. http://www.levistrauss.com/unzipped-blog/tag/recycled-denim/. Accessed 8 Aug 2016.

Li, J., Hartman, S. J., \& Zee, S. M. L. (2009). A study of green movement perceptions and Behavioural intentions. International Journal of Sustainable Economy, 1(2), 133-143.

Lim, W. M., Yong, J. L. S., \& Suryadi, K. (2014). Consumers' perceived value and willingness to purchase organic food. Journal of Global Marketing, 27(5), 287-300.

Loroz, P. S., \& Helgeson, J. G. (2013). Boomers and their babies: An exploratory study comparing psychological profiles and advertising appeal effectiveness across two generations. Journal of Marketing Theory and Practice, 21(3), 289-306.

Luo, W., \& Chung, Q. B. (2015). Retailer reputation and online pricing strategy. Journal of Computer Information Systems, 50(4), 50-56.

Martin, C. A., \& Tulgan, B. (2001). Managing Generation Y. Amherst: Amherst HRD.

Martin, D., \& Schouten, J. (2012). Sustainable marketing. Boston: Prentice Hall.

Martos-Partal, M., \& Gonzales-Benito, O. (2009). The effects of store brand loyalty on store loyalty: Evidence from the Spanish market. The International Review of Retail, Distribution and Consumer Research, 19(3), 273-288.

Nasir, V. A., \& Karakaya, F. (2014). Underlying motivations of organic food purchase intentions. Agribusiness, 30(3), 290-308.

Nielsen (2011). Sustainable Efforts \& Environmental Concerns Around the World. The Nielsen Company. http://www. nielsen.com/us/en/insights/reports/2011/sustainable-efforts-environmental-concerns.html. Accessed 7 June 2016.

Nielsen (2014). Doing well by doing good. The Nielsen Company. http://www.nielsen.com/us/en/insights/reports/2014/ doing-well-by-doing-good.html. Accessed 7 June 2016.

Niinimäki, K. (2011). From disposable to sustainable. The complex interplay between design and consumption of textiles and clothing. Doctoral dissertation. Helsinki: Aalto University.

Niinimäki, K., \& Hassi, L. (2011). Emerging design strategies in sustainable production and consumption of textiles and clothing. Journal of Cleaner Production, 19(16), 1876-1883.

North Face (2016). Recycle, reward, renew. Retrieved August 8, 2016, from https://www.thenorthface.com/about-us/ responsibility/product/clothes-the-loop.html. 
Obucina, V. (2017). Romania shows fast economic growth after 10 years in the EU https://financialobserver.eu/cse-andcis/romania/romania-shows-fast-economic-growth-after-10-years-in-eu/. Accessed 20 June 2017.

Oliver, R. L. (1999). Whence consumer loyalty? Journal of Marketing, 63(Special Issue), 33-44.

Pacheco, B. G., \& Rahman, A. (2015). Effects of sales promotion type and promotion depth on consumer perceptions: The moderating role of retailer reputation. The International Review of Retail, Distribution and Consumer Research, 25(1), 72-86.

Papdopolos, I., Karagouni, G., Trigkas, M., \& Beltsiou, Z. (2014). Mainstreaming green product strategies: Why and how furniture companies integrate environmental sustainability? EuroMed Journal of Business, 9(3), 293-317.

Patagonia (2016). Worn wear. https://wornwear.patagonia.com/. Accessed 10 Aug 2016.

Peattie, K. (2001). Towards sustainability: The third age of green marketing. Marketing Review, 2(2), 129-146.

Pilcher, J. (1994). Mannheim's sociology of generations: An undervalued legacy. Britisch Journal of Sociology, 45(3), 481-495.

Prothero, A., \& Fitchett, J. A. (2000). Greening capitalism: Opportunities for a green commodity. Journal of Macromarketing, 20(1), 46-55.

Puma (2016). Puma launches product recycling program in Puma Stores in Germany. http://about.puma.com/en/ newsroom/corporate-news/2012/april/puma-launches-product-recycling-program-in-puma-stores-in-germany. Accessed 8 Aug 2016.

Rabla H\&M (2015). H\&M demarează programul "Rabla" pentru haine. https://www.dcnews.ro/hm-demareaza-programulrabla-pentru-haine_268212.html. Accessed 8 Aug 2015.

Rajamma, R. K., Pelton, L. E., Hsu, M. K., \& Knight, D. K. (2010). The impact of consumers' need for uniqueness and nationality on generation Y's retail patronage behaviour: Investigating American and Taiwanese consumers. Journal of Global Marketing, 23(5), 387-410.

Roberts, J. A. (1996). Green consumers in the 1990s: Profile and implications for advertising. Journal of Business Research, 36(3), 217-231.

Romanian Statistical Annuary (2014). http://www.insse.ro/cms/files/publicatii/Romania_in_Cifre_2014.pdf. Accessed 10 Nov 2015.

Royne, M. B., Levy, M., \& Martinez, J. (2011). The public health implications of consumers' environmental concern and their willingness to pay for an eco-friendly product. Journal of Consumer Affairs, 45(2), 329-343.

Schramm-Klein, H., \& Steinmann, S. (2014). How sustainable is sustainability? The impact of corporate social irresponsibility on consumer behaviour in retailing. In C. Scholz \& J. Zentes (Eds.), Beyond sustainability (pp. 122-137). Nomos: Baden-Baden.

Sikdar, S. K. (2003). Sustainable development and sustainability metrics. The American Institute of Chemical Engineers Journal, 49(8), 1928-1932.

Sirdeshmkh, D., Singh, J., \& Sabol, B. (2002). Consumer trust, value, and loyalty in relational exchanges. Journal of Marketing, 66, 15-37.

Sisodia, R., Wolfe, D., \& Sheth, J. (2007). Firms of endearment: How world-class companies profit from passion and purpose. Philadelphia: Wharton School Publishing.

Song-Turner, H., \& Polonsky, M. (2016). Enviropreneurial Marketing in Greening Corporate Activities: Evidence from four Chinese green firms. European Business Review, 28(5), 506-531.

Swoboda, B., Berg, B., \& Dabija, D. C. (2014). International transfer and perception of retail formats: A comparison study in Germany and Romania. International Marketing Review, 31(2), 155-180.

Taken Smith, K. (2011). Digital marketing strategies that millennials find appealing, motivating, or just annoying. Journal of Strategic Marketing, 19(6), 489-499.

Taken Smith, K., \& Brower, T. (2012). Longitudinal study of green marketing strategies that influence millennials. Journal of Strategic Marketing, 20(6), 535-551.

Taylor, P., \& Gao, G. (2014). Generation X: America's Neglected 'Middle Child', PewResearch Center. http://www. pewresearch.org/fact-tank/2014/06/05/generation-x-americas-neglected-middle-child/. Accessed 21 July 2016.

Textile Pollution (2016). Cutting textile pollution. https:/cen.acs.org/articles/93/i41/Cutting-Textile-Pollution.html. Accessed 6 Aug 2016.

Verhoef, P. C., Langerak, F., \& Donkers, B. (2007). Understanding brand and dealer retention in the new Car market: The moderating role of brand tier. Journal of Retailing, 83(1), 97-113.

Walsh, G., \& Beatty, S. E. (2007). Customer based corporate reputation of a service firm: Scale development and validation. Journal of the Academy of Marketing Science, 35(1), 127-143.

Walsh, G., Mitchell, V. W., Jackson, P. R., \& Beatty, S. E. (2009). Examining the antecedents and consequences of corporate reputation: A customer perspective. British Journal of Management, 20(2), 187-203.

WBCSD. (2010). Vision 2050: The new agenda for business. Geneva: World Business Council for Sustainable Development. https://www.wbcsd.org/Overview/About-us/Vision2050/Resources/Vision-2050-The-new-agenda-for-business. Accessed 10 Nov 2016.

Weingarten, R. M. (2009). Four generations, one workplace: A gen X-Y staff Nurse's view of team building in the emergency department. Journal of Emergency Nursing, 35(1), 27-30.

Williams, K.C., Page, R.A. (2011), "Marketing to the generations", Journal of Behavioral Studies in Business, Vol. 3, 1-17.

WWF (2016). Earth's resources depleted for 2016. http://www.wwf.ca/?21901/Earths-resources-depleted-for-2016. Accessed 10 Aug 2016.

Young, E. (2015). How millennials get news: Inside the habits of America's first digital generation. Chicago: Associated Press-NORC Center for Public Affairs Research \& American Press Institute.

Yun, Z. S., \& Good, L. K. (2007). Developing customer loyalty from E-tail store image attributes. Managing Service Quality, $17(1), 4-22$.

Ziaullah, M., Feng, Y., \& Akhter, S. N. (2016). How does justice matter in online retailers' reputation and purchase intentions: An empirical study of China. Behaviour \& Information Technology, 0(0), 1-10. 